\title{
ACCOUNTING MANIPULATIONS RELATED TO FINANCIAL ASSETS
}

\author{
Malgorzata Kutera \\ Jagiellonian University, Kraków, Poland \\ ORCID: 0000-0002-7029-2454, e-mail: malgorzata.kutera@uj.edu.pl \\ (C) 2018 Małgorzata Kutera \\ This is an open access article distributed under the Creative Commons Attribution-NonCommercial-NoDerivs license \\ (http://creativecommons.org/licenses/by-nc-nd/3.0/)
}

DOI: $10.15611 / \mathrm{ms} .2018 .3 .03$

JEL Classification: G32, M41, M42

\begin{abstract}
The main purpose of this paper is to present the types and consequences of accounting manipulations concerning financial assets, mainly in the context of their impact on the financial results presented by enterprises. The research methodology is based on a critical analysis of the current legal solutions and case studies. Three different entities audited by the author have been selected to illustrate the most frequently used techniques of accounting manipulations. These relate to the pricing and presentation of blocks of shares listed on the stock exchange as well as shares not traded on a regulated market in the financial statements. The research results unambiguously confirm that the current wording of the provisions of the accounting balance sheet law in this regard leave a rather large degree of freedom in their interpretation. Qualified accountants skilfully use these legal gaps to a significant extent to paint a better picture of the enterprise.
\end{abstract}

Keywords: accounting manipulations, creative accounting, financial assets, share pricing.

\section{Introduction}

In today's economy, investment decisions are still taken based on an analysis of financial statements. The structure and contents of these statements change, but they still present the key figures about the sales, financial results and the asset structure. Individuals responsible for executing them are also aware of this and they try to fabricate desirable results by intentionally exploiting the large degree of freedom offered by the legal regulations. This behaviour has been known for years as creative accounting [Griffiths 1986; Parker 1995; Elliot, Elliot 2000; Surdykowska 2003; Kutera 2016; Wąsowski 2010]. The processes of globalisation, the increasing competition and subsequent economic crises further boosted the trend of window-dressing the asset and its financial standing, as well as the financial results in company statements. Large structures of affiliated entities are established in which the accountants use more and more sophisticated methods.

In this context, financial assets have become an area particularly exposed to the risk of fraud. National and international provisions of accounting balance sheet law governing the valuation and presentation of shares, loans and derivatives in financial statements are quite complicated and the subjective approach to the problem plays too large a role in them. This degree of freedom coupled with the nefarious intentions of the person executing the financial statements poses a high risk to the reliability of the figures presented.

Consequently, the main goal of this paper is to present the types and real consequences of accounting manipulations concerning financial assets, mainly in the context of their impact on the financial results presented by enterprises. The research methodology in this article is based on a critical analysis of the existing legal solutions and a study of cases taken from economic practice. Three different entities audited by the author have been selected to illustrate the most frequently used accounting manipulations. These relate to the pricing and presentation of blocks of shares listed on the stock exchange as well as shares not traded on a regulated market in the financial statements. The last part of this paper additionally presents the scope of liability of individual company bodies for data manipulation. 


\section{The basis for valuing and presenting shares in financial statements}

According to the Act on Accounting, shares acquired by companies established under the Commercial Code can be classified in two ways (art. 3):

- as long-term investments - if the unit intends to control the specific company for a longer period of time and will keep it in its investment portfolio for a period longer than one year from the balance sheet date;

- as short-term investments - if the unit has acquired the shares for the purpose of disposing of them within 12 months of the balance sheet date.

Determining the purpose for which a given ownership title is acquired is of key importance for its correct valuation and presentation in the financial statements. According to the Act on Accounting, shares are priced at (art. 28):

- if they are treated as long-term investments - at their cost minus impairment charges, their fair value or at their value marked to the market;

- if they are short-term investments - at their market value, or alternatively at the lower of their cost or market value (for investments for which there is no active market - at their fair value determined otherwise).

It should be noted that this is also governed by the regulation on the detailed rules of recognising, methods of valuing, the scope of disclosure and the method of presenting financial assets, which in certain areas differs from the requirements of the Act. However, the cases presented in the article concern situations of presenting and valuing shares of subsidiaries to which the regulation does not apply. In economic practice, companies most frequently choose the cost to value this type of financial assets when they buy them. As of the balance sheet date, this value is suitably updated to make the figures presented in the financial statements as reliable as possible. Then, for shares for which there is no regulated market, the cost minus possible impairment charges is used and the securities listed on the stock exchange are valued at the prices quoted as of the balance sheet date.

\section{Contribution in kind of listed shares}

Transactions to establish new companies and take up (or raise) their equity carry a number of risks related to their subjective valuation, especially when they concern affiliated companies. If the equity is fully paid for in cash, there are usually no reservations. Reservations appear when a contribution kind is made. Here, they are not just about the reliable valuation of tangible contributions, but also the correct accounting recording of their transfer to an affiliated company. This topic is all the more important as the literature of the subject describes various solutions in this regard, which have a direct impact the amount of financial result.

As has been mentioned before, entities taking up shares in subsidiaries should value them at cost. If funds are transferred to pay the equity, the situation seems obvious. This is because there is a certain outflow of money which determines the cost of this investment. As of the balance sheet date, the owner of the shares should analyse the operations of the company purchased and possibly make impairment charges or consider presenting the investment at its market value.

The current valuation of acquired shares at cost should also apply when they are contributed in kind. However, some enterprises permit the presentation of assets at their par value. This is due to the recording technique which consists in booking the value of the contribution in kind being transferred to the costs and classifying the par value of the shares acquired as income. This solution is to match the accounting presentation to the corporate income tax regulations in this regard, but is wrong from the point of view of the accounting balance sheet law.

\section{Case description}

In its investment package, Company A held shares of a listed company which it acquired five years earlier. Altogether 2,940,000 shares in Company $\mathrm{B}$ were purchased in several transactions at various prices, which added up to a value at a cost of PLN $30,282,000$. At the same time, Company A also held the majority share of the equity of another Company $\mathrm{C}$ active in the steel industry. During negotiations with Company $\mathrm{C}$, a decision was made to restructure this entity and raise its capital. There were hopes that, in the future, this company would play a major role in selling Polish steel products. The Extraordinary General Meeting of Company A resolved to raise the equity of Company $\mathrm{C}$ and cover it by a contribution in kind consisting of all the shares of Company B it held. As of the day of the equity raise, the price of one share of the company contributed in kind amounted to PLN 20.50. The equity was raised by exactly PLN 60,270,000 (which was the market value of the contribution in kind $-2,940,000$ shares at PLN 20.50 each).

However, an intentional entry was made in the books which also resulted in a significant raising of the financial result of Company A for the period. 
The historical value of the block of shares of Company $\mathrm{B}$ was posted to costs, while the raised value of shares in Company $\mathrm{C}$ was posted to financial assets and, on the other side, to income. As a result the financial result grew by almost PLN 30 million.

Table 1. Financial effects of contributing the shares of the listed Company A in kind

\begin{tabular}{|l|l|}
\hline \multicolumn{2}{|c|}{ BALANCE SHEET } \\
\hline $\begin{array}{l}\text { Assets } \\
\text { - shares of Company B: }\end{array}$ & $\begin{array}{l}\text { Liabilities } \\
\text { - PLN 30,282 thousand }\end{array}$ \\
- $\begin{array}{l}\text { shares of Company C: } \\
\text { + PLN 60,270 thousand }\end{array}$ & \\
\hline PROFIT AND LOSS ACCOUNT \\
\hline - financial costs: PLN 30,282 thousand thousand \\
- financial income: PLN 60,270 thousand = financial result: \\
+ PLN 29,988 thousand \\
\hline
\end{tabular}

Source: developed by the author.

The above method of presenting a contribution in kind to cover the share capital of an affiliated company breaches the regulations of the Act on Accounting which does not allow shares acquired to be valued at their face value. Adopting the above booking technique also has other very important consequences - it directly impacts the amount of the financial result in the period. This fact is skilfully used by companies which, when establishing new affiliated units or raising the equity of existing companies, adjust their financial result in return for the contributions in kind.

Taking up new shares in Company $\mathrm{C}$ should be valued in the books of accounts at cost, which, in this case, is equal to the acquisition value of the shares transferred as a contribution in kind, namely PLN 30,282 thousand. The supporters of the solution used by the company argument that the Act permits a valuation at market value, and in this case, the market value of the shares being transferred is PLN 60,270 thousand. So why can this value not be treated as the market value of the new shares taken up in Company B? This procedure is contrary to the regulations of the Act and the cautionary principle. In the Act, the valuation of investments at market prices applies to analysing their value as of the balance sheet date and is unambiguous in the case of shares of listed companies.

There is another fact that should be noted here. The shares acquired by Company $\mathrm{A}$ in Company $\mathrm{C}$ are treated as long-term investments. Company A already had a majority holding and now raised the equity. If the shares had been recorded at their cost, i.e. PLN 30,282 thousand, the company could have, of course, revalued them to their market value at the end of the year. Assuming that as of the balance sheet date the market value would also be equal to PLN 60,270 thousand, the value of the shares would have to be raised by almost PLN 30 million, but the effect of this valuation would be recognised in the revaluation reserve and not directly in the financial result. The difference, therefore, is obvious.

\section{No impairment charge on shares}

The regulations of the Act on Accounting stipulate that shares in other units and other investments included in fixed assets are valued as of the balance sheet date at cost minus impairment charges, or at their fair value. The method of establishing the real value of such assets is relatively simple when dealing with a regulated market, i.e. the company holds shares of listed entities in its package. Then, the determination of the real value of this asset consists in checking the quotations of individual shares as of the balance sheet date and making the appropriate charges to reduce or raise their value.

The situation is much more complicated if the entity holds shares of companies not listed on a regulated market. How can the real value of those assets be determined then? The proper method most frequently consists in analysing the most recent financial statements of companies held in the investment portfolio and if they are in poor financial standing, making the appropriate impairment charges. Such an impairment charge, on the one hand, reduces the value of assets presented in the balance sheet and on the other, is posted to financial costs and also reduces the financial result of the entity. A special point of reference in such analyses is the amount of net assets of the subsidiary, which indirectly shows if the equity could be repaid to the investors.

\section{Case description}

Entity A bought $80 \%$ of shares in Company B from a natural person under a sales agreement made between these two parties. The selling price was PLN 28 million and was fully paid in cash, half of which came from an investment loan. On the day the agreement was signed, the equity of Company B amounted to PLN 3 million, and the company was financed in $97 \%$ with external capital (mainly bank loans). The main assets of the subsidiary comprise fixed assets, inventories and receivables. Company A presented the shares acquired in Company B at cost, i.e. at the amount of PLN 28 million. For this model of valuation as of the balance sheet date, the cautionary principle applies which requires making impairment charges if there is 
a risk that the value of the asset may be overestimated. The management board of Company A argued that in this case it had no duty to make such a charge, as it had a valuation of Company B executed by an external consulting company, according to which the value of the subsidiarity was PLN 32 million. This was the valuation of the company made using the revenue method and was mainly based on projected net profits which Company B was to generate in the next eight years [Kutera 2016].

Table 2. Financial effects of overestimating the value of shares in Company $\mathrm{A}$

\begin{tabular}{|c|l|}
\hline \multicolumn{1}{|c|}{$\begin{array}{c}\text { Company A } \\
\text { BALANCE SHEET }\end{array}$} & \multicolumn{1}{c|}{$\begin{array}{c}\text { Company B } \\
\text { BALANCE SHEET }\end{array}$} \\
\hline $\begin{array}{l}\text { Assets } \\
\text { - shares of Company B: } \\
\text { PLN 28 million }\end{array}$ & $\begin{array}{l}\text { Liabilities } \\
\text { - equity (net assets): PLN } \\
\text { 3 million constituting 3\% } \\
\text { of the balance sheet total }\end{array}$ \\
\hline
\end{tabular}

Source: developed by the author.

When determining the share selling price between the parties, one of the main documents to be analysed is the balance sheet. This is because this report shows the value of the company equal to the value of its net assets, i.e. its equity. This value corresponds to the difference between the total of the company assets taken over and its liabilities. It thus reflects the real benefit, received by the buyer, if the assets have been valued according to the rules which yield approximate market values.

Taking the above into account, it should be noted that in the case described, the selling price was PLN 28 million, while the net assets taken over were worth PLN 3 million. This means that Company A paid PLN 25 million for intangible benefits taken over together with Company B, e.g. a developed distribution network, its market position and known brand. How can the actual value of such intangible assets be proven? It should be clearly said that in the analysed case it was difficult to find such additional benefits at all.

In this situation, the question arises whether the valuation of financial assets presented in the amount of PLN 28 million in the balance sheet of Company A was at all realistic. At this value of net assets, is there a real chance of recovering the 28 million zlotys paid, and even more, for Company A to gain any economic benefits from this investment (i.e. to receive an amount greater than that paid)? In order to prove that there is no need to make impairment charges on those shares, Company A presented a valuation by the revenue method. However, the expert questioned the reliability of such a method of valuing the company.
How can it be considered reliable to assume a very high level of net profit to be generated in the next eight years as the basis of the valuation if company $B$ never actually reported a profit in the last five years? What is more, the net loss generated from one year to another has gradually been eroding the value of its equity. In this case, an impairment charge on these assets should definitely have been made.

\section{Balance sheet valuation of listed shares}

As mentioned in the previous case, the Act on Accounting stipulates that investments in the form of shares be evaluated for the balance sheet date at cost minus impairment charges or at their fair value. For listed shares, the balance sheet valuation consists in checking the quotations of individual shares on the balance sheet date and making the appropriate charges reducing or raising their value. If the quotation is lower than the price at which the shares had previously been purchased, a revaluation charge posted to financial costs shall be made. In this case it makes no difference whether they constitute long or short-term investments.

In cases of valuing at the market value and making charges raising the value of the reported shares, the distribution over time is of principal importance. The charge raising the value of short-term financial assets is posted to the financial income account and directly influences the financial result. If the same applies to shares which the company treats as longterm investments, the identical charge can be booked only to raise the revaluation reserve (thus, on the other side, the increase in the value of shares raises the equity, but not the financial result of the year).

\section{Case description}

Company A followed a relatively intensive policy of investing in listed shares. At the end of each accounting year, the balance of these shares was significant and according to the historical costs, it ranged from 10 to 15 million zlotys. Informal discussions with the management board indicated that some of these investments were treated as speculative, and some were held for the long term. Long-term investments included, among others, shares of Company B - which was about broadening cooperation, implementing a large joint project and taking over the controlling share of this company. This approach to Company B was also confirmed by its previous classification as a long-term investment. At the end of the $20^{\text {th }}$ century, Company A recorded unsatisfactory financial results. The preliminary version of the financial statements presented a loss of about 1 million zlotys and the 
shares of Company B were, as always, presented in long-term investments. After analysing all accounting possibilities of improving the result, the entity suddenly changed its strategy concerning Company B and made the assumption that these financial assets were speculative. As a result, the entire surplus from the balance sheet valuation of these shares (PLN 2.5 million) was deducted from the revaluation reserve and added to financial income. The audited entity turned a loss of PLN 1 million into a profit of PLN 1.5 million. The false assumption of the speculative nature of company B shares adopted for the balance sheet valuation was confirmed in subsequent reporting periods, because the discussed company still holds these shares today.

Table 3. Financial effects of distorting the balance sheet valuation of shares in the books of Company $\mathrm{A}$

\begin{tabular}{|c|c|}
\hline \multicolumn{2}{|c|}{ BALANCE SHEET } \\
\hline $\begin{array}{l}\text { Assets } \\
\text { - shares of Company B: } \\
\text { + PLN } 2.5 \text { million }\end{array}$ & $\begin{array}{l}\text { Liabilities } \\
\text { - financial result: + PLN } 2.5 \\
\text { million }\end{array}$ \\
\hline \multicolumn{2}{|c|}{ PROFIT AND LOSS ACCOUNT } \\
\hline \multicolumn{2}{|c|}{$\begin{array}{l}\text { - financial revenue: + PLN } 2.5 \text { million } \\
\text { = financial result: + PLN } 2.5 \text { million }\end{array}$} \\
\hline
\end{tabular}

Source: developed by the author.

Classifying shares as long or short-term investments is a subjective decision. The reference point is the intention to keep the asset for a period longer or shorter than one year from the balance sheet date. However, the above classification is decisive for the way the effects of the balance sheet valuation are booked, particularly with reference to financial assets valued at fair value.

If the price of listed shares is higher on the balance sheet date than the historical cost, the subjective shifting of shares from long-term to short-term investments leads directly to 'artificially' increasing the financial result. In many cases the auditor is helpless as it is difficult to effectively prove to the company that it actually has no intention to sell these shares within the coming accounting year.

\section{Scope of liability for financial data manipulation}

The greatest role in preventing the negative consequences of the mechanisms presented above is played by statutory auditors. Legal regulations clearly provide which companies are obliged to have their financial statements audited before their approval by the general meeting and publication. In
Poland, pursuant to Art. 64 of the Act on Accounting, the annual financial statements must be verified by all joint stock companies (which include banks, brokerage houses, in-vestment fund companies etc.). The remaining companies under the commercial law, civil-law partnerships and natural persons conducting business activity must submit to an obligatory audit if their financial statements for the previous accounting year exceeded at least two of the following three values:

- average annual employment in excess of 50 FTEs,

- total assets on the balance sheet equal to the Polish zloty equivalent of at least EUR 2,500,000,

- net revenues from the sales of goods, products and financial operations for the accounting year equal to the Polish currency equivalent of at least EUR 5.000.000.

In all the above cases, statutory auditors verify the annual financial statements, books of accounts and source documents forming the basis for the presentation of data in financial/accounting systems. The audit results in the issuing of the statutory auditor's report which may be of a different nature, depending on the extent to which the adjustments suggested by the auditor have been made. If significant irregularities have not been adjusted in the financial statements, the auditor should issue a qualified or a negative opinion. Hence the type of the statutory auditor's report issued and its content clearly indicate the scale of possible fraud. The obligatory publication of the auditors' reports for listed companies and their filing with the registry court by all other companies subject to verification means that the audit results are generally accessible and particular attention should be paid to them.

In this context, the scope of liability for the integrity of company financial statements should be clearly described. Art. 4 in conjunction with Art. 77 of the Act on Accounting clearly states that it is the manager of the unit (i.e. the management board) and the supervisory board members who are obliged to ensure the regularity of the financial statements and bear joint and multiple civil and criminal liability. The auditor, in turn, is responsible for the correct type of opinion they issued on the financial statements presented by the company. This means that if the financial statements contain material errors, the auditor may not issue an unqualified opinion (art. 78 of the Act on Accounting).

In the context of this subject, a special role is also played by the audit committee, which should closely cooperate with the statutory auditor during their audit. The audit committee has clearly defined duties with regard to the integrity of the financial statements and the audit process itself. Art. 130 of the Act on statutory 
auditors, audit firms and public supervision lists the following among the main tasks of the committee:

- monitoring the financial reporting process within the company and the process of financial statement auditing by the audit firm;

- controlling and assessing the independence of the statutory auditor and the audit firm;

- developing the rules of auditor selection;

- informing the supervisory board of the audit results and clarifying how the audit has contributed to the integrity of the financial reporting;

- presenting recommendations aimed at ensuring the integrity of the financial reporting process.

The investors in business undertakings are the main addressees of the information disclosed in financial statements and the conclusions from the audit. If the reported figures raise their doubts and this is supported by the qualified opinion of the statutory auditor, they should express this at the general meeting and vote against approving the financial statements. In certain situations the law actually prohibits the effective approval of the financial statements, including if the statutory auditor's opinion is negative.

\section{Conclusion}

The examples of accounting manipulations related to shares presented in this article clearly show how big the risk of subjectively applying legal regulations governing this area is. The problems concern both the valuation and also the presentation of data in company financial statements. They relate to shares on the regulated market, but also to transactions in shares traded outside such a market. The example of contributing listed shares in kind clearly shows that the problem is not just about evaluating the contribution in kind, but also the intentional booking resulting in a significant increase of the net profit. An intentional boosting of the financial result has also been demonstrated in the case concerning the balance sheet valuation of shares listed on a regulated market, which is considered to be one of the least controversial areas of accounting balance sheet law. The financial result can also be protected by intentionally avoiding to make impairment charges for shares. The case presented to this effect has clearly shown how significant an impact subjectivity can have on the choice of the method and the results of valuing financial assets.

The results of this research clearly confirm that the current regulations of the accounting balance sheet law concerning the valuation and presentation of shares in financial statements leaves a rather large degree of freedom in their interpretation. Qualified accountants skilfully exploit these legal gaps, to a significant extent, to create a better image of the enterprise. In many cases these manipulations have a direct impact on the main economic category which the financial result of the company represents.

\section{Bibliography}

AICPA, 2002, Examples of Fraud Risk Factors, Statement on Auditing Standard No. 99, App. 1.

Bragg S., 2007, Accounting Best Practices, John Wiley \& Sons Inc., New Jersey.

Elliot B., Elliot J., 2000, Financial Accounting and Reporting, Financial Times Prentice Hall, p. 567.

Griffiths J., 1986, Creative Accounting, Sidgwick \& Jackson, London.

Hołda A., Kutera M., Surdykowska S., 2006, Oszustwa księgowe. Teoria i praktyka, Centrum Doradztwa i Informacji Difin Sp. z o.o., Warszawa, pp.15-23.

Kutera M., 2016, Naduzycia finansowe. Wykrywanie i zapobieganie, Difin S.A., Warszawa.

Międzynarodowy Standard Badania nr 240, Odpowiedzialność biegłego rewidenta podczas badania sprawozdań finansowych dotyczaca oszustw, Załącznik nr 1.5 do uchwały 2783/52/2015 Krajowej Rady Biegłych Rewidentów z dnia 10 lutego $2015 \mathrm{r}$.

Parker R., 1955, Financial Reporting on the United Kingdom and Australia, Prentice Hall, London.

Rezaee Z., Riley R., 2010, Financial Statement Fraud. Prevention and Detection, John Wiley \& Sons Inc., New Jersey.

Schilit H.M., 2010, Financial Shenanigans. How to Detect Accounting Gimmicks \& Fraud in Financial Reports, The McGraw Hill Companies.

Surdykowska S., 2003, Kreatywna inżynieria księgowa, Nasz Rynek Kapitałowy, $\mathrm{nr} 1$.

Ustawa z 29 września 1994 r. o rachunkowości, Dz. U. 2016, poz. 1047.

Wąsowski W., 2010, Kreatywna rachunkowość. Fatszowanie sprawozdań finansowych, Difin SA, Warszawa.

Wells J.T., 2006, Nadużycia w firmach. Vademecum, Wydawnictwo Prawnicze LexisNexis Sp. z o.o., Warszawa. 


\section{MANIPULACJE KSIEGOWE W ZAKRESIE AKTYWÓW FINANSOWYCH}

Streszczenie: Głównym celem opracowania jest prezentacja rodzajów i skutków manipulacji księgowych w zakresie aktywów finansowych, głównie w kontekście ich wpływu na prezentowane wyniki finansowe przedsiębiorstw. Podstawę metodyki badawczej stanowi analiza krytyczna istniejących rozwiązań prawnych oraz studium przypadków. Wybrano trzy różne podmioty, które były audytowane przez autora, i na ich podstawie przedstawiono najczęściej stosowane techniki nadużyć księgowych. Dotyczą one wyceny oraz prezentacji w sprawozdaniach finansowych pakietów akcji notowanych na giełdzie, jak również udziałów niepodlegających rynkom regulowanym. Wyniki badań jednoznacznie potwierdzają, że obecny stan regulacji prawa bilansowego w tym zakresie pozostawia dość duży zakres swobody w ich interpretacji. Wykwalifikowani księgowi umiejętnie korzystają z tych luk prawnych i w znaczącym stopniu wykorzystują je do kreowania lepszego obrazu przedsiębiorstwa.

Słowa kluczowe: manipulacje księgowe, rachunkowość kreatywna, aktywa finansowe, wycena udziałów i akcji. 